\title{
Pemberdayaan Masyarakat Pedesaan Melalui Transformasi Nilai-Nilai Kewirausahaan dalam Pelaksanaan Program Desa Mandiri Cinta Petani (Sari Tani) di Kecamatan Insana, Kabupaten Timor Tengah Utara
}

\author{
Stefanus Bekun ${ }^{\mathrm{a}}$, Agustinus L. Tiza ${ }^{\mathrm{b}}$ \\ ${ }^{a}$ Fakultas Ilmu Sosial dan Ilmu Politik, Universitas Timor, Kefamenanu, Indonesia. \\ ${ }^{b}$ Fakultas Ilmu Sosial dan Ilmu Politik, Universitas Timor, Kefamenanu, Indonesia.
}

\section{Article Info}

Article history:

Received 2 November 2016

Received in revised form 14 November 2016

Accepted 11 Desember 2016

\section{Keywords:}

Pemberdayaan

Transformasi Nilai Kewirausahaan

Desa Mandiri Cinta Petani

Sari Tani

\section{Abstrak}

Penelitian bertujuan untuk mendeskripsikan dan menganalisis pemberdayaan masyarakat pedesaan melalui Program Sari Tani serta transformasikan nilai-nilai kewrirausahaan kepada masyarakat desa melaui Program Sari Tani di Kecamatan Insana Kabupaten Timor Tengah Utara. Metode yang digunakan adalah metode kualitatif. Hasil penelitian menunjukkan Target pengurangan KK Miskin selama 5 tahun RPJMD adalah Tahun 2010 sebesar 65,62\% atau 36.225 KK, Tahun 2011 sebesar $61.92 \%$ atau 34.182 KK, Tahun 2012 sebesar $58.22 \%$ atau 32.139 KK, Tahun $201354.52 \%$ atau 30.097 KK, Tahun 201 sebesar 50.82 \% = 28.054 KK dan Tahun 2015 sebesar 47.12 $\%$ atau 26. 012 KK. Prosentase penurunan per tahun adalah: $3.7 \%$. Sehingga akumulasi penurunan prosentase kemiskinan di Kabup aten TTU selama lima tahun adalah sebesar 18.53\%. Di tahun 2015 diharapkan jumlah KK miskin di TTU: 26.012 KK. Jumlah penduduk miskin di Kabupaten TTU menurut Data Terpadu PPLS tahun 2011 adalah 31.175 KK atau sebesar 55,54 \% dari 56. 494 KK. Tahun 2012 , data BPS menunjukkan bahwa jumlah penduduk miskin di Kabupaten Timor Tengah Utara: 51.200 jiwa atau 25.600 KK atau 44,47 \% Dalam implementasinya progran Sari Tani bertujuan meningkatkan populasi ternak. Tetapi dalam pelaksanaan Sari Tani belum berjalan baik yang disebabkan karena 1) masyarakat masih memposisikan dirinya sebagai obyek dalam program Sari Tani, sehingga cenderung untuk tidak pro aktif dalam pengelolaan dana; 2) Pendamping Kelompok Masyarakat (PKM) belum memahami tupoksinya secara baik dan benar; 3) Unit Pelaksana Sari Tani (UPST) belum memahami tupoksinya secara baik dan benar; 4) Rendahnya dukungan Pemerintah Desa; 5) Sikap dan perilaku masyarakat yang masih terikat dengan budaya (adat istiadat) sehingga pola pikir terhadap program Sari Tan belum memadai. Kondisi ini menjadi tantangan dalam mentransformasi semangat kewirausahan bagi masyarakat dalam mengembangkan dirinya menjadi masyarakat yang madiri, terutama secara ekonomi. (02017 dipublikasikan oleh Agrimor.

\section{Pendahuluan}

Persoalan mendasar dalam proses penyelenggaran pemerintahan, baik di tingkat pusat, daerah, maupun desa adalah bagaimana membangun atau menciptakan mekanisme pemerintahan yang dapat mengemban misinya dalam mewujudkan masyarakat yang sejahtera secara berkeadilan. Karena itu, pemerintah harus melaksanakan pembangunan berdasarkan aspirasi masyarakat, dan memberikan pelayanan publik dengan sebaik-baiknya.

Dengan diberlakukanya kebijakan otonomi daerah sesunguhnya mengisyaratkan agar pemerintah daerah harus mampu untuk mengoptimalkan pemanfaatan semua potensi yang dimiliki daerah tersebut. Melalui kebijakan otonomi daerah diharapkan dapat membangun kemandirian dalam menentukan seluruh kegiatannya sehingga pemerintah daerah tidak selalu berada dalam bayang-bayang pemerintah pusat. Artinya, bahwa pemerintah daerah harus memilki kemampuan untuk memainkan perannya dalam memajukan daerah dengan mengoptimalkan potensi yang ada. Pemberian otonomi kepada daerah sesungguhnya bertujuan untuk meningkatkan daya guna dan hasil guna penyelenggaraan pemerintahan dalam meningkatkan pembangunan dan pelayanan kepada masyarakat.

Konsep otonomi daerah tidak dapat dilepaskan dari pemahaman terhadap asas desentralisasi. Rondinelli yang dikutip Dwiyanto (2003) mengemukakan bahwa desentralisasi merupakan perpindahan kewenangan atau pembagian kekuasaan dalam perencanaan pemerintah dan manajemen serta pengambilan keputusan dari tingkat nasional ke tingkat daerah. Intinya adalah pelimpahan kewenangan atau kekuasaan kepada pemerintah daerah; yang dalam realisasinya diwujudkan dalam bentuk otonomi daerah yang seringkali dimaknai sebaga kepemilikan kekuasaan untuk mengatur rumah tangga sendiri dan mengelolanya demi mencapai tujuan bersama yang telah disepakati bersama masyarakat Dengan demikian sesungguhnya desentralisasi memiliki sesuatu tujuan politik yang penting yakni memberikan kesempatan munculnya partisipasi mayaraka dan kemandirian daerah serta menjamin kecermatan pejabat publik dalam memberikan pelayanan kepada masyarakatnya".

Selain itu pada tingkat pragmatis, desentralisasi dianggap sebagai cara untuk mengatasi berbagai hambatan kelembagaan, fisik, budaya maupun administratif dalam melaksanakan tugas-tugas pembangunan. Prinsipnya adalah mendekatkan kebijakan dan pelayanan pemerintah yang diimplementasikan melalui berbagai cara termasuk upaya melakukan perencanaan dan pelaksanaan pembangunan daerah dalam kancah otonomi daerah yang disesuaikan dengan kondisi lokal sehingga pembangunan dapat berjalan dengan lebih lancar dan efektif.

Kebijakan pembangunan dalam rangka menjawab tantangan sebagaimana disebutkan di atas adalah upaya peningkatan pemerataan pembangunan beserta hasil-hasilnya melalui arah kebijakan pembangunan sektoral dan pemberdayaan masyarakat (people empowering) terutama di pedesaan oleh karena penduduk Indonesia sebagian besar bermukim di pedesaan dengan segala problematika seperti kemiskinan, keterbelakangan serta kerawanan sosial yang membelenggu masyarakat desa.

Untuk itu, Muhi (2012) menyatakan bahwa secara umum pembangunan desa meliputi dua aspek yang sangat penting, yakni 1) Aspek fisik, yaitu pembangunan yang obyek utamanya dalam aspek fisik; 2) Aspek pemberdayaan insani, yaitu pembangunan yang obyek utamanya aspek pengembangan dan peningkatan kemampuan, skill, dan memberdayakan masyarakat di daerah pedesaan sebagai warga negara. Tujuan utamanya adalah untuk membatu asyarakat yang masih tergolong marginal agar dapat melepaskan diri dari belenggu keterbelakangan sosial, ekonomi, politik dan lain sebagainya".

Selama ini yang tampak bahwa perjalanan pembangunan daerah masih didominasi oleh strategi yang menempatkan pembangunan pedesaan pada posis yang terpisah dari pembangunan perkotaan. Baik dari rencana pembangunan yang disusun maupun dalam bentuk implementasi yang diterapkan, pemerintah daerah tampak masih diilhami dan dipandu oleh pemikiran bahwa pembangunan pedesaan memiliki kerakteristik, regulasi, perkembangan dan perubahan yang berlainan dengan pembangunan perkotaan.

Posisi masyarakat desa yang bersifat semi otonom dengan segala perangka yang dimilikinya merupakan modal dasar dalam perencanaan pembangunan dengan prinsip partisipasi. Jaringan organisasi yang terdapat di dalam struktur masyarakat pedesaan merupakan jalur penyampaian pendapat dan pembahasan keputusan yang solid. Dalam konteks pembangunan sebenarnya mempunya kaitan resikprokal. Kaitan resikprokal itu ada hubungan yang signfikan antara diversifikasi dan peningkatan hasil produk dipedesaan dengan pertumbuhan kota, hubungan antara diversifikasi dengan peningkatan dipedesaan dengan tumbuhnya pusat - pusat perdagangan diperkotaan. Hal ini terjadi karena pemerintah daerah hanya meningkatkan pembangunan perkotaan sehingga dipedesaan masih sangat tertinggal dengan pembangunan yang masih minim, dalam hal ini pembangunan di desa masih sangat relatif rendah.

Oleh karena itulah pendekatan pembangunan desa harus dilakukan secara hati-hati dan didasari oleh pemahaman yang baik atas masyarakat desa yang bersangkutan. Menurut Chambers (1996), bahwa memahami desa secara partisipatif mencerminkan adanya perkembangan pendekatan dan metode yang memungkinkan masyarakat desa saling berbagi, menambah, dan menganalisis pengetahuan tentang kondisi kehidupannya dalam upaya membuat perencanaan dan tindakan.

Dalam hal demikian, pembangunan pedesaan merupakan suatu proses yang membawa peningkatan kemampuan penduduk pedesaan menguasai lingkungan sosial yang disertai meningkatnya taraf hidup mereka sebagai akibat dari penguasaan tersebut. Untuk itu, pembangunan desa sebagai suatu proses melalu langkah-langkah yang meliputi dua dimensi sebagai berikut; Dimensi pertama merupakan dimensi formal. Langkah-langkah dalam dimensi ini merupakan tahapan yang harus dilalui dalam perencanaan atau penentu program pembangunan dan biasanya telah ditentukan dari atas atau disepakati bersama oleh anggota komunitas. Dimensi kedua adalah dimensi substansial. Dimensi ini meliputi langkah-langkah yang terdapat dalam mekanisme pengambilan keputusan dan didalamnya tersirat adanya pergulatan kepentingan dan pelaksanaan fungsi institusional ataupun aktor-aktor (stakeholders) yang bermain didalam struktur tertentu pada masyarakat

Keterlibatan masyarakat dalam perencanaan pembangunan sering disebut dengan partisipasi masyarakat. Hal ini sebagaimana dikemukakan oleh Sastrodipoetro dalam Safi'i (2008), bahwa partisipasi diartikan sebagai keterlibatan komunitas setempat secara aktif dalam pengambilan keputusan atau pelaksanaannya terhadap proyek-proyek pembangunan. Akan tetapi dalam pelaksanaannya pola bottom up planing yang lebih mengutamakan partisipasi masayarakat belum berjalan sebagaimana yang diharapkan.

Lebih lanjut Najih et al., (2006) juga mengemukakan pengalamanpengalaman yang telah terjadi sebagai akibat rendahnya pelibatan masyarakat dalam proses perencanaan pembangunan telah memperlihatkan dampak negatif sebagai berikut; 1) rendahnya rasa memiliki dari masyarakat atas proyek-proyek pembangunan yang disusun, yang mengakibatkan keberlanjutan (subtainnability) dari program yang dilaksanakan tidak terwujud. 2) munculnya biaya transaksi (transaction coast) yang sangat mahal karena masyarakat kurang memahami tujuan program/proyek pembangunan sehingga muncul penolakan atas program/proyek yang dilaksanakan. 3) program/ proyek pembangunan wilayah yang tidak sesuai dengan kebutuhan dan karakteristik masyarakat. 4) 
lunturnya kepercayaan masyarakat pada pemerintah. 5) terjadinya pencemaran dan kerusakan lingkungan.

Dalam konteks perencanaan pembangunan daerah, mekanisme perencanaan dari bawah tidak lebih sebagai mata rantai birokrasi yang membuat desa tergantung pada kabupaten. Desa dijadikan sebagai tempat membuang bantuan program pembangunan, yang dalam prakteknya proses perencanaan pembangunan di tingkat kabupaten/ kota berjalan secara mekanisme yang tidak dihasilkan melalui berbasis pada partisipasi dari desa. Pada umumnya, perencanaan pembangunan daerah kurang memperhatikan usulan dari desa sehingga rencana pembangunan tahunan daerah yang dihasilkan melalui kegiatan Musrenbang dan Rencana Kerja Pemerintah Daerah masih merupakan hasil rencana birokrasi tingkat kabupaten dan kurang mengakomodir usulan prioritas kegiatan Pemerintah Desa yang telah disepakati melalui Musyawarah Perencanaan Pembangunan Desa (Musrenbangdes) maupun musyawarahmusyawarah yang diselenggarakan oleh lembaga-lembaga mitra pemerintah.

Pendekatan pengambilan keputusan dalam pembangunan yang dilakukan di daerah masih menggunakan pola top down, sehingga memposisikan masyarakat (desa) sebagai objek dalam setiap program pembangunan dan keterlibatan atau partisipasi masyarakat dalam program tersebut merupakan kemauan sepihak dari atas untuk menyukseskan program dimaksud. Hal Ini membawa masyarakat ke dalam situasi ketidakberdayaan untuk menampilkan citra dan harga diri sebagai manusia yang memiliki aspirasi, keinginan dan harapan. Selama ini model pembangunan yang dianut pada masa orde baru yang menempatkan masyarakat dalam posisi marginal dan bukan pada posisi sentral sebagai subjek, sekaligus objek pembangunan itu sendiri. Hal ini sebagai akibat dari program dan kegiatan yang direncanakan oleh pemerintah sebagai program dan kegiatan yang mencerminkan kebutuhan yang dinyatakan sebagai prioritas program dan kegiatan, sementara apa yang diusulkan oleh masyarakat hanya merupakan keinginan yang tidak harus direalisasikan, bahkan harus dihilangkan/dikeluarkan dari daftar usulan rencana pembangunan.

Akibat dari proses pengambilan keputusan itu dapat melumpuhkan partisipasi masyarakat dalam proses perencanaan pembangunan karena proses dan seluruh tahapan pembangunan (mengidentifikasi masalah, perencanaan, pelaksanaan, pengawasan, dan tindak lanjut) telah didominasi oleh pemerintah. Kondisi ini sangat berpengaruh dalam proses perencanaan pembangunan, sehinggamembuat masyarakat apatis terhadap setiap program yang diperuntukan baginya karena masyarakat beranggapan bahwa program dan kegiatan tersebut merupakan program dan kegiatan pemerintah dan bukan sebagai solusi untuk memecahkan persoalan masyarakat. Kenyataan ini, telah membawa perubahan paradigma baru dalam hal perencanaan pembangunan dimana masyaraka sebagai pemegang kedaulatan harus diberikan ruang untuk turut berpartisipasi dalam proses perencanaan pembangunan dalam era otonomi daerah ini.

Keterlibatan masyarakat secara langsung sangat diperlukan dalam proses perencanaan pembangunan, mulai dari tahap identifikasi, penggalian gagasan, perencanaan program/kegiatan, pelaksanaan program/kegiatan, pelestarian program/kegiatan dan pengendalian program/kegiatan, sebagai salah satu aspek penting dalam proses pemberdayaan masyarakat menuju kemandirian masyarakat sehingga masyarakat benar-benar turut merasa memiliki dan turut bertanggung jawab atas hasil pembangunan demi peningkatan kesejahteraan hidupnya lahir dan batin.

Sehubungan dengan itu, dapat dikatakan bahwa suatu keniscayaan apabila program dan kegiatan pembangunan yang ingin meningkatkan kesejahteraan suatu komunitas (masyarakat) tertentu, tanpa melibatkan masyarakat terutama masyarakat miskin atau rumah tangga miskin. Dengan demikian, untuk mencapai keberhasilan dari suatu program pembangunan maka kata kunci yang harus mendapat perhatian adalah keterlibatan masyarakat terutama masyarakat miskin sebagai suatu keharusan yang tidak dapat ditawar, karena keputusan pembangunan yang kurang melibatkan masyarakat, dapat menimbulkan sikap apatis, frustasi, kecemburuan sosial, dan ketidapercayaan terhadap pemerintah sehingga persoalan kemiskinan dan pengangguran tidak dapat diatasi, bahkan setiap tahun semakin meningkat dan menjadi beban pembangunan.

Untuk menopang pelaksanaan pembangunan kemasyarakatan tersebut perlu usaha yang terencana baik dalam upaya pembangunan sarana-sarana pendukung, sarana perhubungan, produksi, sarana pemasaran dan prasarana lainnya untuk peningkatan taraf hidup dan kesejahteraan masyarakat yang lebih baik.Seiring bergulirnya reformasi, tuntutan untuk memberdayakan masyarakat terutama masyarakat kelas bawah adalah merupakan hal yang harus dilakukan, sebab fenomena pemberdayaan masyarakat adalah merupakan siklus yang terus menerus. Dengan mengoptimalkan sumberdaya yang ada diharapkan masyarakat yang berdaya akan dapat tercapai. Untuk itu pemerintah melalui Badan-Badan atau Dinas terkait, memfasilitasi proses-proses pemberdayaan tersebut, melalui berbagai program kemasyarakatan, pembinaan dan pemberian stimulan untuk menggairahkan pembangunan desa serta pemberian pelatihan keterampilan dalam upaya pemberdayaan masyarakat.

Kemiskinan disadari sebagai fenomena sosial yang telah lama ada. Berkembang sejalan dengan peradaban manusia. Untuk itu, Hakim, (2007) menegaskan bahwa kemiskinan merupakan masalah yang sangat kompleks, baik dilihat dari sisi peyebabnya maupun dampak yang ditimbulkannya. Kompleksitas ini tampak dari konsepsi kemiskinan itu sendiri yang tidak hanya menyangkut persoalan ekonomi yang ditandai oleh rendahnya tingkat pendapatan dan kualitas hidup tetapi juga menyangkut persoalan sosal, budaya dan hukum yang ditandai oleh ketidakberdayaan, ketertinggalan,ketidakadilan dan marginalisasi, kemiskinan adalah situasi serba kekurangan yang terjadi bukan karena dikehendaki oleh si miskin, melainkan karena tidak dapat dihindari dengan kekuatan yang ada padanya.

Permasalahan kemiskinan semakin hari menjadi sangat kompleks. Belum lagi jika dikaitkan dengan adanya hidden interest di balik program penanggulangan kemiskinan yang mana berbagai kepentingan politik ikut terlibat di dalamnya. Para pejabat politik menempatkan kebijakan-kebijakan yang berkaitan dengan program-program yang mengarah pada upaya membebaskan masyarakat dari belenggu kemiskinan sebagai bagian dari agenda poitik mereka untuk menarik simpati masyarakat dalam proses politik sesaat (seperti misalnya supaya terpilih dalam sebuah perhelatan politik pemilihan kepala daerah). Dampak yang dihasilkan dari pola pikir ini adalah memunculkan ketergantungan masyarakat terhadap pola pembangunan yang bersifat karitatif atau bantuan sesaat.

Kelemahan lain dari model pembangunan yang dikembangkan untuk mengatasi kemiskinan adalah adanya kesan yang sangat kuat akan intervensi pemerintah dalam setiap peroses penyelenggaraan pembagunan, mulai dari tingkat perencanaan hingga pelaksanaannya. Pemerintah memprogramkan berbagai upaya pembangunan yang dikelola melalui mekanisme birokrasi dan proses pembangunan bercirikan perembesan dari atas. Walupun pemerintah secara formal mengatakan bahwa partisipasi rakyat merupakan unsur yang paling penting dalam pembangunan sekaligus untuk menciptakan keberhasilan pembangunan.

Dalam upaya untuk meningkatkan kualitas hidup masyarakat pemerintah tidak cukup hanya mengucurkan dana bantuan kepada masyarakat atau upayaupaya yang sifatnya karitatif semata, karena hal yang demikian justru akan rawan bias dan justru memperlebar ketimpangan dan kesenjangan antar kelas, sementara disisi lain, upaya-upaya karitatif dengan cara menyantuni secara penuh dan menjadikan keluarga-keluarga miskin menjadi obyek justru akan menimbulkan ketergantungan saja di pihak mereka yang disantuni serta menjadikan masyarakat miskin semakin tidak berdaya, maka model pembangunan yang perlu dikembangkan adalah pembangunan pemberdayaan.

Masyarakat Kabupaten Timor Tengah Utara sebagian besar adalah petan yang senantiasa mengandalkan sektor pertanian sebagai sumber utama untuk memenuhi kebutuhan hidupnya. Dengan segala kemampuan yang ada, mereka berusaha untuk meningkatkan kesejahteraan hidupnya. Untuk itu, perhatian pembangunan perlu diarahkan kepada pembangunan pedesaan dan kemasyarakatan, karena sebagian besar masyarakat berada di pedesaan maka wajar bila pembangunan dan pemberdayaan difokuskan pada pembangunan desa dengan segala aspeknya, baik aspek kemasyarakatan maupun pelayanan publik pedesaan melalui pemerintahan desa. Hal ini dilakukan karena masih banyaknya masyarakat kita yang diliputi dengan masalah kemiskinan, keterbelakangan dan berbagai kerawanan sosial lainnya.

Mengacu dari berbagai pandangan di atas menunjukkan bahwa terdapat permasalahan mendasar dalam penyelenggaraan pembangunan daerah di Kabupaten Timor Tengah Utara. Permasalahan-permasalahan tersebut dapat dikategorikan sebagai berikut:

a. Tingginya angka kemiskinan. Tingkat perkonomian masyarakat Kabupaten TTU ditunjukkan oleh beberapa indikator yakni pertumbuhan PDRB, PDRB per kapita serta persentase penduduk di bawah garis kemiskinan Pertumbuhan ekonomi daerah yang ditunjukkan oleh laju pertumbuhan PDRB dan pendapatan perkapita mengalami perkembangan yang cukup baik meski trendnya fluktuatif. Jumlah penduduk miskin di Kabupaten TTU menurut Data Terpadu PPLS tahun 2011 adalah $31.175 \mathrm{KK}$ atau sebesar $55,54 \%$ dari 56.494 KK. Tahun 2012, data BPS menunjukkan bahwa jumlah penduduk miskin di Kabupaten Timor Tengah Utara: 51.200 jiwa atau $25.600 \mathrm{KK}$ atau $44,47 \%$.

b. Rendahnya kualitas sumber daya manusia. Kemiskinan berimplikasi pada rendahnya kualitas sumber daya manusia di Kabupaten TTU karena dengan kondisi tersebut masyarakat tidak mampu memperoleh pendidikan formal yang baik sehinggga SDM masyarakat masih rendah dan kondisi kesehatan masyarakat yang buruk. Mengacu pada Data Dinas Pendidikan Pemuda dan Olah Raga, Kabupaten Timor Tengah Utara Tahun 2010 menunjukkan bahwa jumlah penduduk buta huruf (usia 10 tahun ke atas) pada tahun 2006 sampai 2010 berturut-turut mencapai 36.796 jiwa, 29.476 jiwa, 23.486 jiwa, 17.866 lalu menurun menjadi 12.556 jiwa pada kondisi 2010. Trend penurunan jumlah penduduk buta huruf ini mengindikasikan performance $\mathrm{d}$ bidang pendidikan yang cukup baik. Kendati demikian, angka ini masih tergolong tinggi sehingga membutuhkan intervensi kebijakan yang cukup intens. Selain angka buta huruf, tingkat pendidikan masyarakat di Kabupaten Timor Tengah Utara yang masih rendah dapat dilihat dari angka rata-rata lama sekolah yang hanya 6,7 tahun pada tahun 2010. Artinya rata-rata penduduk hanya menamatkan sekolah dasar sederajat.

c. Masalah rawan bencana alam. Wilayah Kabupaten TTU sering dilanda bencana alam seperti banjir, tanah longsor dan kekeringan yang mengakibatkan kerusakan pada lahan pertanian masyarakat. Mengacu pada Rekapitulasi Kecamatan dan Desa yang Mengalami Rawan Pangan tahun 2010 menunjukkan bahwa di Kabupaten Timor Tengah Utara terdapat 15 Kecamatan, 64 Desa, 12.679 Kepala Keluarga dan 63.395 jiwa mengalami resiko rawan pangan.

Terhadap berbagai permasalahan di atas, tentunya sangat dibutuhkan suatu kebijakan publik yang populis sehingga masyarakat dapat keluar dari keterbelengguan tersebut. Secara sederhana kebijakan publik dapat dipahami 
sebagai keputusan-keputusan yang mengikat bagi orang banyak dalam tataran strategis atau bersifat garis besar yang dibuat oleh pemegang otoritas publik. Meskipun begitu tidak ada konsensus yang mengatur secara pasti mengenai definisi yang diberikan untuk memahami kebijakan publik ini. Studi yang dilakukan oleh Thomas A. Birdfucker (2001) yang dikutip Darumurti et al., (2007) menjelaskan bahwa terdapat beberapa karakteristik yang bisa dipakai untuk menjelaskan kebijakan publik. Karakteristik tersebut diantaranya adalah kebijakan dibuat atas nama publik, pada umumnya dibuat dan atas inisiatif pemerintah, kebijakan diinterpretasikan dan diimplementasikan oleh publik serta pihak lain, kebijakan adalah apa yang secara intens dilakukan oleh pemerintah.

Lain lagi dengan pendapat yang dikemukakan James Anderson dalam Darumurti et al., (2007) bahwa terdapat dua aktor yang terlibat dalam pembuatan kebijakan, yakni pertama adalah Official Policy Markers, yaitu organ-organ yang menduduki pos-pos kekuasaan secara resmi atau legal. Yang termasuk dalam kategori ini adalah para anggota legislatif, para administrator dan hakim pengadilan. Kedua adalah Unofficial Policy Markers, yaitu organ-organ yang secara formal memang tidak tidak mempunyai wewenang untuk merumuskan kebijakan publik tetapi kegiatan-kegiatannya banyak mempengaruhi official policy markers. Golongan ini sering berpartisipasi dalam proses pembuatan kebijakan, dan partisipasi mereka itu memang dibenarkan. Yang termasuk dalam golongan ini adalah kelompok-kelompok kepentingan, partai politik, media massa dan warga negara secara individual",

Mengacu dari karakteristik kebijakan tersebut di atas, maka sejumlah kebijakan pembangunan yang diarahkan untuk meningkatkan kesejahteraan masyarakat telah dilakukan oleh Pemerintah Kabupaten Timor Tengah Utara, baik kebijakan pendistribusian sumber pembangunan dari pusat maupun yang bersumber dari kebijakan daerah dalam upaya memacu perkembangan kemasyarakatan. Salah satu program yang digalakan adalah menghadirkan Program Padat Karya Pangan (PKP). Program Padat Karya Pangan (PKP) bertujuan untuk meningkatkan ketahanan pangan masyarakat desa, yang diatur melalui Peraturan Daerah Kabupaten Timor Tengah Utara Nomor 4 Tahun 2011 tentang Rencana Pembangunan Jangka menengah Daerah (RPJMD) Kabupaten Timor Tengah Utara tahun 2011-2015. Dalam RPJMD ini, Program Padat Karya Pangan menjadi bagian dari salah satu program strategis Bupati TTU yakni program pengembangan pertanian yang dikemas dalam Program Desa Mandiri Cinta Petni (Sari Tani) menuju Pensiun Petani sebagai replikasi dari Program Pembangunan Desa Mandiri Anggur Merah.

Program pengembangan pertanian menjadi perioritas utama di Kabupaten TTU untuk menjawab persoalan kemiskinan. Dengan argument ini, pertanian ditempatkan sebagai lokomotif pembangunan daerah yang mampu menarik "gerbong" bidang pembangunan lainnya. Asumsinya bahwa pertanian yang maju akan memperbaiki ekonomi rakyat, memajukan pendidikan dan kesehatan masyarakat, berkontribusi secara signifikan terhadap pelestarian lingkungan hidup serta dapat mendorong penguatan koperasi dan Usaha Kecil Menengah. Dengan spirit "gerakan cinta petani", diupayakan pengembangan pertanian melalui beberapa program prioritas diantaranya Program Padat Karya Pangan dengan tujuan utamanya adalah menciptakan ketahanan pangan dan penigkatan pendapatan petani.

Program-program yang mengarah pada penanggulangan kemiskinan di pedesaan sebenarnya secara konseptual memiliki makna yang strategis. Permasalahan utamanya adalah pada tahapan implementasinya yang kurang signifikan. Kebanyakan mind set para implementor program masih berorientasi proyek, sehingga substansi yang sebenarnya mengenai pemberdayaan dan partisipasi masyarakat belum tersentuh. Keyataan ini mengakibatkan terjadinya pragmatisme dan kembali pada paradigma lama bahwa masyarakat miskin ditempatkan sebagai obyek dari sebuah kebijakan (program). Masyarakat miskin kurang digairahkan sebagai pelaku utama dari sebuah program. Dengan demikian implementasi program menjadi terkesan jauh dari tujuan dan sasaran yang sesungguhnya.

Kenyataan empirik menunjukkan adanya kontradiktif berbagai upaya peningkatan kesejahteraan masyarakat dengan berbagai kebijakan yang dihasilkan. Antara harapan dan kenyataan tidak selalu berjalan linier akan tetapi senantiasa selalu berbenturan yang pada gilirannya menimbulkan ketimpangan antara harapan dan realitas. Harapan yang diletakkan pada Program Desa Mandiri Cinta Petani belum menemui wujud nyata dalam menuntaskan berbagai problematika kehidupan masyarakat. Kesejahteraan yang menjadi tujuan utama program justru belum menampakkan hasil yang diharapkan

Berbagai program yang dicanangkan tersebut belumlah menunjukkan hasil yang maksimal sebagai upaya penanggulangan kemiskinan di Kabupaten Timor Tengah Utara. Untuk itu, dalam rangka mendukung terwujudnya cita-cita dalam mengurangi angka kemiskinan di daerah kabupaten/kota, Pemerintah Kabupaten TTU mengembangkan suatu strategi yang dikemas melalui Sari Tani.

Di Kabupaten TTU pemberdayaan masyarakat melalui Program Sari Tani dimaksudkan untuk mentransformasikan nilai-nilai kewirausaahaan kepada masyarakat, yakni inovasi dan kreativitas, semangat kompetitif, meningkatkan kualitas kerja, sikap berani mencoba, percaya diri, inisiatif, tanggungjawab, berani mengambil resiko. Program ini mengandung empat pengertian dasar yakni : 1) sebagai upaya penanggulangan kemiskinan masyarakat desa; 2) sebagai upaya Pengembangan ekonomi produktif melalui pemberian bantuan dana bergulir sebagai modal usaha bagi masyarakat miskin: 3) Sebagai strategi untuk mengembangkan produk unggulan kabupaten, dan; 4) Sebagai upaya untuk menguatkan kapasitas fiskal desa.
Komoditas yang diandalkan dikabupaten TTU yakni : jagung, kacang tanah, bawang putih siung tunggal, ternak sapi dan garam. Jenis komoditas yang dipilih untuk dikembangkan di suatu desa, berdasarkan potensi desa tersebut untuk mendukung pengembangan dan peningkatan produksi salah satu atau lebih dari kelima produk unggulan dan pengembangan ternak babi serta pengembangan bawang putih lokal. Sesuai dengan potensi wilayah, maka jenis komuditas yang dapat dikembangkan disuatu desa terlihat pada Tabel 1.

\section{Tabel 1. Pengembangan Komuditas Unggulan}

\begin{tabular}{|c|c|c|}
\hline No & Komoditas & Nama desa \\
\hline 1. & Jagung & Semua desa \\
\hline & Kacang tanah & Semua desa \\
\hline & $\begin{array}{l}\text { Bawang putih siung } \\
\text { tunggal }\end{array}$ & $\begin{array}{l}\text { Tasinifu, Noepesu, Fatuneno, Saenam, Manusasi, } \\
\text { Eban, salu, Lemon, Sunae, Fatunaisuan, Sa'tab, Jak } \\
\text { dan Tunoe. }\end{array}$ \\
\hline & Ternak sapi & Semua desa \\
\hline & Garam & $\begin{array}{l}\text { Humusu C, Oesoko, Oepuah Utara, ponu, Tuamese, } \\
\text { Motadik. }\end{array}$ \\
\hline & Ternak Babi & $\begin{array}{l}\text { Semua desa. } \\
\text { Tasinifu, , noepesu, Fatuneno, Saenam, Manusas }\end{array}$ \\
\hline
\end{tabular}

7. Bawang putih lokal Eban, Salu, Lemon, sunae, Fatunaisuan, Sa,tab, Jak Sumber: Kecamatan Insana, 2016 dan Tunoe.

Penelitian bertujuan untuk mendeskripsikan dan menganalisis pemberdayaan masyarakat pedesaan melalui Program Sari Tani serta transformasikan nilai-nilai kewrirausahaan kepada masyarakat desa melaui Program Sari Tani di Kecamatan Insana Kabupaten Timor Tengah Utara.

\section{Metode}

Penulisan menggunakan metode kualitatif. Penggunaan metode ini diharapkan mampu menyajikan bentuk yang menyeluruh (holistic) dalam menganalisis fenomena Program Sari Tani di Kecamatan Insana. Strauss dan Corbin, (1998) mengemukakan bahwa penelitian kualitatif merupakan penelitian yang menghasilkan penemuan-penemuan yang tidak dapat diperoleh dengan mengunakan prosedur statistik atau dengan cara lain dari kuantifikasi (pengukuran)

Setelah data dikumpulkan, proses selanjutnya adalah menyederhanakan data ke dalam bentuk yang mudah dibaca, dipahami dan diinterpretasi sebagai suatu upaya peneliti untuk mencari jawaban atas permasalahan yang dirumuskan. Dengan demikian, metode analisis data yang digunakan dalam penelitian ini adalah analisis data kualitatif dengan model analisis interaktif (interactive model analysis) yang dikembangkan oleh Miles dan Huberman, (1994) dengan prosedurnya, sebagi berikut; a) Data Reduction (Reduksi Data) yakni merangkum, memilih dan memfokuskan pada pengambilan data yang pokok/penting sesuai dengan focus peneltian. Dengan demikian, data telah direduksi akan memberikan gambaran yang lebih jelas dan mempermudah peneliti untuk melakukan pengumpulan data selanjutnya serta mencarinya bila diperlukan; b) Data Display (Penyajian Data) yakni display data dengan maksud agar data yang sudah dihimpun akan terorganisasikan, tersusun dalam pola hubungan sehingga akan semakin mudah dipahami. Dengan penyajian data dapa memudahkan peneliti untuk memahami apa yang terjadi, merencanakan kerja selanjutnya berdasarkan apa yang telah dipahami tersebut, dan; c) Conclusion Data/Drawing/Verivication (Kesimpulan Data) yakni melakukan penarikan kesimpulan dan verifikasi. Kesimpulan awal yang dikemukakan masih bersifat sementara dan akan berubah bila belum ditemukan bukti-bukti yang kuat yang medunkung pada tahap pengumpulan data berikutnya. Tetapi apabila kesimpulan yang dikemukakan pada tahap awal, didukung oleh bukti yang valid dan konsisten saat peneliti kembali ke lapangan mengumpulkan data, maka kesimpulan yang dikemukakan merupakan kesimpulan yang kredibel.

\section{Hasil dan Pembahasan}

\subsection{Pemberdayaan Masyarakat Pedesaan Melalui Program Sari Tani}

Program Desa Mandiri Cinta Petani yang diakronimkan menjadi Sari Tani, merupakan salah satu program unggulan Pemerintah Kabupaten Timor Tengah Utara (TTU), yang dicetuskan Bupati TTU periode 2010-2015 Raymundus Sau Fernandes bersama Wakil Bupati Aloysius Kobes. Program ini mulai diaplikasikan pada tahun 2011. Pada awal masa kepemimpinan Bupati Raymundus Sau Fernandes dan Wakil Bupati Aloysius Kobes di akhir tahun 2010, jumlah keluarga miskin di Kabupaten TTU sebesar 65,62 persen atau 31.375 Kepala Keluarga Miskin. Hal tersebut berarti sebagian penduduk di Kabupaten TTU berada pada kategori miskin. Kondisi itu diakibatkan oleh kurang tersedianya lapangan kerja yang dapat memberikan penghidupan yang layak bagi masyarakat.

Meskipun sekitar 90 persen angkatan kerja di Kabupaten TTU merupakan tenaga kerja yang terserap pada lapangan kerja, namun dalam kenyataannya telah terjadi pengangguran terselubung. Sekitar 70 persen tenaga kerja merupakan pekerja yang tidak diupah. Akibatnya, angka kemiskinan tinggi karena ketidakmampuan memenuhi kebutuhan pokok.

Tingginya angka kemiskinan tersebut telah menjadi perhatian serius pemerintah, sehingga dalam Rencana Pembangunan Jangka Menengah Daerah (RPJMD) Tahun 2011-2015 menempatkan kemiskinan sebagai salah satu isu strategis yang membutuhkan Penanganan secara tepat. Untuk Kabupaten Timor 
Tengah Utara, penurunan angka kemiskinan cukup signifikan sebagaimana terlihat dalam Gambar 1.

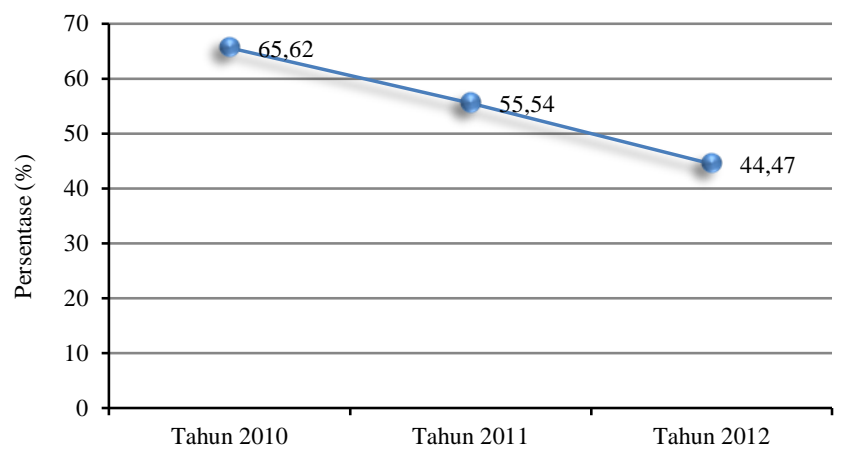

- Persentase penduduk miskin Kab. TTU

Sumber: RPJMD Penyelarasan Kabupaten TTU, 2014

\section{Gambar 1. Trend Penurunan Angka Kemiskinan TTU}

Gambar 1. memberikan gambaran bahwa target pengurangan KK Miskin selama 5 tahun RPJMD adalah Tahun 2010 sebesar $65,62 \%$ atau $36.225 \mathrm{KK}$, Tahun 2011 sebesar $61.92 \%$ atau $34.182 \mathrm{KK}$, Tahun 2012 sebesar $58.22 \%$ atau 32.139 KK, Tahun $201354.52 \%$ atau $30.097 \mathrm{KK}$, Tahun 201 sebesar 50.82 $\%=28.054 \mathrm{KK}$ dan Tahun 2015 sebesar $47.12 \%$ atau 26. $012 \mathrm{KK}$. Prosentase penurunan per tahun adalah: $3.7 \%$. Sehingga akumulasi penurunan prosentase kemiskinan di Kabupaten TTU selama lima tahun adalah sebesar $18.53 \%$. Di tahun 2015 diharapkan jumlah KK miskin di TTU: 26.012 KK. Jumlah penduduk miskin di Kabupaten TTU menurut Data Terpadu PPLS tahun 2011 adalah 31.175 KK atau sebesar 55,54 \% dari 56. $494 \mathrm{KK}$. Tahun 2012, data BPS menunjukkan bahwa jumlah penduduk miskin di Kabupaten Timor Tengah Utara: 51.200 jiwa atau $25.600 \mathrm{KK}$ atau $44,47 \%$.

Pada masa pemerintahan kepala daerah sebelumnya, ada sejumlah upaya yang dilakukan untuk menanggulangi kemiskinan, antara lain Program Kredit Usaha Tani (KUT), Kredit Ketahanan Pangan (KKP), Inpres Desa Tertinggal (IDT), Nusa Tenggara Agricultiure Area Development Project (NTAADP), Program Pengembangan Kecamatan (PPK), Bantuan Langsung Tunai (BLT), Program Nasional Pemberdayaan Masyarakat (PNPM) Mandiri Pedesaan, serta masih banyak program lainnya yang bertujuan mengentaskan kemiskinan di masyarakat.

Namun, kebiajakan penanggulangan kemiskinan tersebut didesain secara sentralistik dengan program-program yang sifatnya memanjakan masyarakat. Berbagai kebijakan pemerintah yang bersifat sentralistik tersebut belum membawa perubahan yang signifikan terhadap pola piker masyarakat akan konsep pemberdayaan yang sesungguhnya. Sebagaimana dikemukan Sulistiyani, (2004), bahwa tahapan pemberdayaan, sebagai berikut

a. Tahap penyadaran dan pembentukan perilaku menuju perilaku sadar dan peduli sehingga merasa membutuhkan peningkatan kapasitas diri.

b. Tahap transformasi kemampuan berupa pengetahuan, kecakapan keterampilan agar terbuka wawasan dan memeberikan keterampilan agar terbuka wawasan dan memberikan keterampilan dasar sehingga dapat mengambil peran didalam pembangunan.

c. Tahap peningkatan kemampuan intelektual, kecakapan keterampilan sehingga terbentuklah inisiatif dan kemampuan inovatif untuk mengantarkan pada kemandirian.
Merubah pola pikir merupakan sejumlah faktor yang berpengaruh terhadap pelaksanaan program pemberdayaan masyarakat yang telah diterapkan, diantaranya pola piker masyarakat yang masih menganggap bahwa bantuan/program pemberdayaan tersebut merupakan pemberian gratis dari pemerintah kepada masyarakat dan tidak dipertanggungjawabkan. Selain itu, seleksi calon penerima bantuan sangat subyektif dan tidak tepat sasaran.

Lemahnya pengawasan dalam penyaluran, dan penggunaan kreditpun turut berpengaruh sehingga kredit lebih banyak digunakan untuk keperluan konsumtif daripada usaha produktif. Pemahaman masyarakat bahwa dana yang diberikan merupakan dana hibah yang tidak perlu dikembalikan, membuat masyarakat tidak bertanggungjawab menggunakannya.

Program yang didesain secara sentralistik dari pusat itupun tidak mempertimbangkan kondisi social masyarakat tiap daerah, sehingga program tersebut belum tentu dapat diterapkan secara merapa disemua daerah. Melihat kelemahan berbagai program penanggulangan kemiskinan yang diterapkan pemerintahan terdahulu, sejalan dengan semangat RPJMD 2011-2015, Pemerintah Kabupaten TTU dibawah kepemimpinan Bupati Raymundus Sau Fernandes dan Aloysius Kobes, merasa perlu mengembangkan strategi dan alternative penanggulangan kemiskinan yang berpihak pada rakyat miskin. Berpihak kepada rakyat miskin dapat diartikan bahwa masyarakat miskin diberi kesempatan seluas-luasnya untuk menentukan apa yang akan dijalankan dalam upaya mengangkatnya keluar dari garis kemiskinan. Tugas pemerintah hanyalah sebagai fasilitator dan mengawasi pelaksanaan kegiatan.

Pemikiran pendekatan pedesaan tersebut yang menjadi spirit pelaksanaan Program Desa Mandiri Cinta Petani. Program Sari Tani adalah program pengentasan kemiskinan dengan pendekatan pembangunan di pedesaan yang diarahkan untuk meningkatkan kemandirian masyarakat melalui pengembangan berbagai produk unggulan sesuai ketersediaan potensi sumberdaya, agar tercapai peningkatan pendapatan.

Secara umum, tujuan program Sari Tani Kabupaten TTU adalah meningkatkan kesejahteraan masyarakat desa mnelalui penciptaan kesempatan kerja yang berfokus pada pengembangan usaha ekononomi produktif. Secara spesifik, tujuan program Sari Tani adalah untuk menurunkan angka kemiskinan masyarakat desa dan meningkatkan kesempatan berusaha masyarakat desa, terutama yang berpenghasilan rendah.

Dukungan Pemerintan Desa untuk mengawal program Sari Tani juga sangat menentukan keberhasilan program, karena program ini dilaksanakan oleh kelompok masyarakat di desa. Sebagai ujung tombak keberhasilan program Sar Tani di lapangan, Pendamping Kelompok Masyarakat (PKM) memiliki peranan yang sangat penting. Tugas mereka dalam memfasiltasi kelompok penerima dana Sari Tani dibilang cukup berat oleh karena bagaimana membantu merubah pola pikir dan perilaku masyarakat menuju kemandirian dalam berusaha.

Selain itu, program Sari Tani tersebut juga dilaksanakan untuk mengembangkan produk unggulan kabupaten (prukab) serta memperkuat kapasitas fiskal desa. Peningkatan pendapatan sebagai sasaran yang ingin dicapai dari program Sari Tani, adalah meningkatnya pendapatan masyarakat desa $\mathrm{Rp}$ 4.081.912 di tahun 2011 menjadi Rp 4.803.026 pada tahun 2015, dan menurunkan presentasi keluarga miskin di pedesaan dari 65,62\% di tahun 2011 menjadi $47,12 \%$ pada tahun 2015

Sasaran lainya, terciptanya 720 unit usaha produktif baru dikalangan masyarakat pedesaan pada tahun 2015 , dan terbentuknya 144 unit lembaga keuangan desa yang sehat di tahun 2015. Selain itu, sasaran program tersebut juga untuk mewujudkan lima jenis produk unggulan kabupaten di tahun 2015 dan meningkatkan rata-rata Pendapatan Asli Desa (PADes) dari Rp 1.500.000, di tahun 2011 menjadi Rp 7.500.000,- di tahun 2015. Berikut data alokasi dan realisasi Penggunaan Dana Sari Tani.

Tabel 2. Data Alokasi dan Realiasasi Dana Sari Tani Kecamatan Insana

\begin{tabular}{|c|c|c|c|c|c|}
\hline No & Nama Desa & Jumlah Dana & Realisasi & Sisa & Jenis Kegiatan \\
\hline 1. & Susulaku B 2012 & 248.850 .000 & 217.503 .300 & 118.820 .000 & Paronisasi Sapi \\
\hline 2. & Oinbit 2013 & 247.500 .000 & 134.625 .000 & 112.875 .000 & Paronisasi Sapi, Ternak Babi \\
\hline 3. & Sekon 2013 & 250.000 .000 & 94.800 .000 & 155.200 .000 & Paronisasi Sapi, Ternak Babi \\
\hline 4. & Manunain B & 164.285 .000 & 106.395 .000 & 57.890 .000 & Paronisasi Sapi, Ternak Babi \\
\hline 5. & Nansean & 246. 185.000 & 108.680 .000 & 137.505 .000 & Paronisasi Sapi \\
\hline 6. & Keun & 241.680 .000 & 90.910 .000 & 150.770 .000 & Penggemukan Babi, Paronisasi Sapi, Ternak Babi \\
\hline 7. & Fatuana & 246.185 .000 & 92.600 .000 & 153.585 .000 & Paronisasi Sapi \\
\hline 8. & Loeram & 248.850 .000 & 217.503.000 & 30.747 .000 & Paronisasi Sapi \\
\hline 9. & Botof & 159.000 .0000 & - & - & Paronisasi Sapi \\
\hline 10. & Tapenpah & 218.450 .000 & 218.450 .000 & & Paronisasi Sapi \\
\hline 11. & Nansean Timur & 192.180 .000 & - & - & Paronisasi Sapi, Penggemukan Babi \\
\hline 12. & Susulaku & 232.390 .000 & 89.325 .000 & 143.065 .000 & Paronisasi Sapi, Penggemukan Babi \\
\hline Total & & 3.880 .370 .000 & 1.370 .791 .300 & 1.060 .457 .000 & \\
\hline
\end{tabular}

Sumber : Kecamatan Insana, 2016

Tabel 2. menjelaskan bahwa dari total dana yang dialokasikan ke 12 (dua belas) kelompok sebesar $\mathrm{Rp} 3.880 .370 .000,-$ terealisasi sebesar $\mathrm{Rp}$ 1.370.791.300 dan masih terdapat $\mathrm{Rp}$ 1.066.457.000 yang masih harus dikembalikan. Dengan demikian, guna mengefektifkan dan menyukseskan pelaksanaan Program Desa Mandiri Cinta Petani "Sari Tani" maka diperlukan Tim Pelaksana dan Tim Koordinasi yang kuat dan solid pada semua tingkatan pemerintah. Pelaksanaan Program Sari Tani yang kini memasuki tahun keenam Dalam rentang waktu tersebut terdapat berbagai kendala. Beberapa kendala dimaksud, sebagai berikut 1) masyarakat masih memposisikan dirinya sebagai obyek dalam program, sehingga kurang pro aktif dalam mengeloladan program; 2) Pendamping belum memahami tupoksinya secara baik dan benar. Pendamping yang bukan anak asli desa bersangkutan jarang datang ke desa dampingan, PKM 
belum mampu mengorganisir kelompok secara baik, PKM jarang berkoordinasi dengan pemeritah desa, Absensi kehadiran PKM secara keseluruhan ditandatagani oleh kepala desa tanpa mengetahui frekuensi kehadiran PKM di Desa, Pemberian dana transport kepada PKM tanpa memeperhatikan frekuensi keharidan dan kinerja PKM; 3) UPST belum memahami tupoksinya secara bain dan benar, Minimnya pelatihan bagi UPST berdampak pada rendahnya pemahaman UPST terhadap administrasi kelompok dan teknik pengorganisasian kelompok, PKM tidak tinggal di lokasi dampingan berimplikasi langsung terhadap fungsi ganda yang harus menjadi beban UPST, Minimnya SDM UPST; 4) Rendahnya dukungan pemerintah desa. Pemerintah desa seringkali bersikap apatis terhadap penagihan dana pinjaman kelompok padahal dana Sari Tani dana abadi di desa yang peruntukannya bagi peningkatan kesejahteraan masyarakat desa, Yang terjadi selama ini bahwa pengembalian pinjaman dana Sari Tani dapat ditagih jika dibantu oleh pemerintah kecamatan. Malahan pada beberapa desa, aparat desanya tidak berada di tempat ketika tim kecamatan turun melakukan penagihan pinjaman, Pemerintah Desa mengalokasikan biaya transport bagi PKM dalam APBDes, dan tetap membayar biaya transport tersebut walaupun PKM kurang bertanggungjawab terhadap tugas, Kepala desa tetap membubuhkan tanda tangan pada absensi PKM walaupun mengetahui rendahnya frekuensi kehadiran PKM di desa.

Terhadap berbagai permasalahan sebagaimana terungkap di atas dalam pelaksanaan Program Sari Tani, maka sudah tentu harus diatasi sedini mungkin demi keberhasilan pencapaian tujuan program. Untuk hal tersebut, diharapkan peran serta aktif dari semua pihak yang dalam hal ini Camat selaku Ketua Tim Koordinasi, Kasie Perekonomian sebagai Ketua Tim Pelakaksana Program Sari Tani, para Kepala Desa, para Pendamping Kelompok Masyarakat, Unit Pelaksana Program Sari Tani (UPST) sebagai pengelola kegiatan di desa, juga masyarakat penerima manfaat sehingga terbentuk sinergi positif secara komprehensif dan integral dan bertujuan meningkatkan kesejahteraan masyarakat. Tanpa komitmen ini, maka bukan mustahil program ini akan sia-sia. Semua pihak memiliki tanggungjawab yang sama dalam menyukseskan program Sari Tani.

\subsection{Strategi Mentransformasi Nilai-nilai Kewirausahaan Melalui Program \\ Sari Tani}

Transformasi semangat kewirausahaan sebagai pemasukan virus mental kedalam setiap anggota masyarakat di pedesaan melalui berbagai cara, yang dikemukakan Wasistiono, (2003) yakni melalui penyuluhan/ sosialisasi; melalui pemberian contoh nyata; melalui pemberian kesempatan berusaha; dan melalui proses pembelajaran secara terus-menerus melalui program pendampingan. Strategi mentransformasikan nilai-nilai kewirausahaan dalam program Sari Tani yakni melalui sosialisasi, Pemberian contoh nyata, Pemberian kesempatan, dan Proses pembelajaran secara terus-menerus. Staregi ini dilakukan didasari oleh pemikiran bahwa pemerintah mempunyai tanggungjawab yang besar dalam menanamkan nilai-nilai inovavati dan kreatif kepada masyarakat.

Dengan demikian, program Sari Tani dilaksanakan dengan pola pendampingan yang maksimal dan didukung oleh komunikasi yang efektif diantara elemen program. Komunikasi yang intensif diantara pelaku program akan memberikan kejelasan serta menghindari pembiasan keberadaan program. Untuk itu, Seksi Ekonomi sebagai pihak yang bertanggung jawab terhadap program ini perlu menjalin komunikasi dengan para pelaku program yakni Pendamping Kelompok Masyarakat (PKM), pemerintah Kecamatan dan Pemerintah Desa yang dilakukan secara terus menerus baik dalam bentuk Rapat Koordinasi yang dilakukan di Kabupaten, Kecamatan dan Desa, juga dilakukan melalui sosialisasi program, juga melalui kunjungan langsung ke kelompok masyarakat. Dengan terbangunnya komunikasi yang intensif tentunya kami berharap para pemangku kepentigan di wilayah kabupaten ini dapat bersinergi sehingga kita semua memiliki komitmen untuk kesuksesan program.

Sebagai pelaku program ditingkat kecamatan, pemerintah kecamatan juga memiliki tanggungjawab yang besar terhadap keberhasilan program. Sesuai dengan dengan perannya dalam malakukan pembinaan dan pengendalian serta menjembatani antara pemerintah desa dengan pemerintah kabupaten tentunya membutuhkan kesamaan pemikiran tentang program Sari Tani.

Mengacu pada beragam pendapat yang dikemukakan di atas, dalam pelaksanaan program Sari Tani indikator pencapaian untuk meningkatkan kesejahteraan masyarakat desa melalui penciptaan kesempatan kerja yang berfokus pengembangan usaha eknomi produktif. Secara umum, indikator capaian keberhasilan program dapat dijabarkan dalam tujuan program sesuai Pedoman Pelaksanaan Program Desa Mandiri Cinta Petani Kabupaten Timor Tengah Utara Tahun 2012-2015 (BPMPD Kab. TTU, 2013), sebagai berikut:

1. Meningkatnya pendapatan masyarakat dari Rp 4.081.912 di tahun 2011 menjadi Rp 4.803.026 di tahun 2015 .

2. Menurunkan prosentase keluarga miskin di pedesaan dari $65,62 \%$ keluarga di tahun 2011 menjadi 47,12\% keluarga di tahun 2015 .

3. Terciptanya 720 unit usaha produktif di kalangan masyarakat pedesaan di tahun 2015.

4. Terbentuknya 144 unit lembaga keuangan desa yang sehat di tahun 2015 .

5. Terwujudnya 5 jenis produk unggulan kabupaten di tahun 2015 .

6. Meningkatnya rata-rata Pendapatan Asli Desa (PADes) dari Rp $1.500 .000 \mathrm{di}$ tahun 2011 menjadi Rp 7.500.000 di tahun 2015

Hasil penelitian menunjukkan bahwa indikator capaian di atas belum menunjukan kebehasilan secara signifikan dikarenakan oleh beberapa hal, seperti masih banyak kelompok penerima manfaat yang belum memahami secara baik tujuan pengelolaan dana Sari Tani, disisi lain bahwa kelompok penerima manfaat belum secara maksimal menerapkan pengetahuan dan keterampilan sesuai usaha tani yang dikembangkan. Hal lain yang sangat berpengaruh pada pencapaian tujuan pelaksanaan program Sari Tani adalah bahwa kondisi sosial budaya di mana masyarakat masih sangat terikat kuat dengan urusan adat, apabila tidak dilaksanakan akan mendatangkan malapetaka, jadi wajib dilaksanakan. Kewajiban inilah yang membuat perubahan sikap terhadap program menjadi masalah. Kebiasaan masyarakat yang tidak mau mengmbalikan dana bergulir itu sudah ada sejak lama karena tidak ada tindaklanjut yang berkaitan dengan ketegasan memberikan sanksi”.

Terhadap kenyataan diatas, maka seluruh komponen program dari tingkat Kabupaten kecamatan, desa, pendamping dan anggota kelompok/masyaraka penerima manfaat perlu berkoordinasi dengan baik agar Program Sari Tani ini benar-benar dapat membentuk karakter kewirausahaan kepada masyarakat. Hal ini dimaksudkan agar menciptakan kemandirian masyarakat desa dalam menata kehidupan mereka ke arah yang lebih baik, lebih maju dan lebih berkembang. Melalui strategi mentaransformasikan nilai-niai kewirausahaan tersebut akan membentuk karakter kewirausahaan, seperti :

a. Berorientasi ke masa depan, bukan hanya masa lalu

b. Berani mengambil resiko dengan penuh perhitungan

c. Berani bertanggungjawab terhadap keputusan yang diambil, tampa

berupaya melimpahkan kesalahan pada pihak lain.

d. Memegang teguh janji

e. Penuh daya kreativitas dan inovasi

f. Cenderung berpikir positif

g. Sangat menghargai waktu

Hal ini ditegaskan Frinces, (2009), bahwa salah satu aspek penting membangun strategi adalah menanamkan jiwa dan semangat kewirausahaan yakni adanya kemauan yang kuat untuk berubah, selalu membangun kepercayaan diri yang tinggi, selalu bersikap positif. Dengan demikian maka melalui Program Sari Tani akan mentransformasikan nilai-nilai kewirausaahaan kepada masyarakat, yakni inovasi dan kreativitas, semangat kompetitif, meningkatkan kualitas kerja, sikap berani mencoba, percaya diri, inisiatif, tanggungjawab, berani mengambil resiko. Namun, upaya mentransformasikan nilai-nila kewirausahaan ini belum dapat terwujud oleh karena pola pikir dan perilaku masyarakat yag masih sangat terikat dengan buadaya (adat istiadat) setempat Terhadap hal ini, para pelaku program mesti secara terus menerus memotivasi masyarakat agar terjadi perubaha pola pikir dan perilaku tersebut.

\section{Simpulan}

Target pengurangan KK Miskin selama 5 tahun RPJMD adalah Tahun 2010 sebesar $65,62 \%$ atau $36.225 \mathrm{KK}$, Tahun 2011 sebesar $61.92 \%$ atau $34.182 \mathrm{KK}$, Tahun 2012 sebesar 58.22\% atau 32.139 KK, Tahun $201354.52 \%$ atau 30.097 KK, Tahun 201 sebesar $50.82 \%=28.054$ KK dan Tahun 2015 sebesar $47.12 \%$ atau 26. 012 KK. Prosentase penurunan per tahun adalah: $3.7 \%$. Sehingga akumulasi penurunan prosentase kemiskinan di Kabupaten TTU selama lima tahun adalah sebesar $18.53 \%$. Di tahun 2015 diharapkan jumlah KK miskin di TTU: 26.012 KK. Jumlah penduduk miskin di Kabupaten TTU menurut Data Terpadu PPLS tahun 2011 adalah 31.175 KK atau sebesar 55,54 \% dari 56. 494 KK. Tahun 2012, data BPS menunjukkan bahwa jumlah penduduk miskin di Kabupaten Timor Tengah Utara: 51.200 jiwa atau 25.600 KK atau 44,47\%.

Dalam implementasinya progran Sari Tani bertujuan meningkatkan populasi ternak. Tetapi dalam pelaksanaan Sari Tani belum berjalan baik yang disebabkan karena 1) masyarakat masih memposisikan dirinya sebagai obyek dalam program Sari Tani, sehingga cenderung untuk tidak pro aktif dalam pengelolaan dana; 2) Pendamping Kelompok Masyarakat (PKM) belum memahami tupoksinya secara baik dan benar; 3) Unit Pelaksana Sari Tani (UPST) belum memahami tupoksinya secara baik dan benar; 4) Rendahnya dukungan Pemerintah Desa; 5) Sikap dan perilaku masyarakat yang masih terikat dengan budaya (adat istiadat) sehingga pola pikir terhadap program Sari Tani belum memadai. Kondisi in menjadi tantangan dalam mentransformasi semangat kewirausahan bag masyarakat dalam mengembangkan dirinya menjadi masyarakat yang madiri, terutama secara ekonomi.

\section{Pustaka}

BPMPD Kab. TTU, 2013. Pedoman Pelaksanaan Program Desa Mandiri Cinta Petani Kabupaten Timor Tengah Utara Tahun 2012-2015.

Chambers, R., 1996. PRA: Participatory Rural Appraisal, Memahami Desa Secara Partisipatif. Kanisius.

Darumurti, A., Erawan, M.A., Putra, I.K., 2007. Institusi Informal dan Kebijakan Publik di Aras Lokal:: Studi tentang Eksistensi dan Kontribusi Institusi Informal dalam Proses agenda Setting serta Implementasi Kebijakan Publik di Desa Krecek Kecamatan Pare Kabupaten Kediri. Universitas Gadjah Mada.

Dwiyanto, A., 2003. Reformasi tata pemerintahan dan otonomi daerah: Ringkasan eksekutif. Pusat Studi Kependudukan dan Kebijakan, Universitas Gadjah Mada.

Frinces, Z.H., 2009. Kepemimpinan berbasis kewirausahaan. Mida Pustaka. Hakim, A., 2007. Dinamika Sosial Ekonomi Masyarakat Pedesaan. Lembaga Penerbitan dan Dokumentasi FIA-UB, Malang. 
Miles, M.B., Huberman, A.M., 1994. Qualitative Data Analysis: An Expanded Sourcebook. SAGE.

Muhi, A.H., 2012. Fenomena Pembangunan Desa. Institut Pemerintahan Dalam Negeri, Jatinangor.

Najih, M., Watch, M.C., Indonesia, Y.P.P.I. dan K.M., 2006. Hak rakyat mengontrol negara: membangun model partisipasi masyarakat dalam penyelenggaraan otonomi daerah. Diterbitkan atas kerjasama Malang Corruption Watch (MWC) [dengan] Yappika.

Safi'i, M., 2008. Paradigma baru kebijakan pembangunan ekonomi daerah: pengembangan model kebijakan pembangunan ekonomi daerah, belajar dari pengalaman Kabupaten Hulu Sungai Selatan periode 1998-2003 dan 20042006. Averroes Press.

Strauss, A., Corbin, J.M., 1998. Basics of Qualitative Research: Techniques and Procedures for Developing Grounded Theory. SAGE Publications.

Sulistiyani, A.T., 2004. Kemitraan dan model-model pemberdayaan. Gava Media.

Wasistiono, S., 2003. Kapita Selekta Manajemen Pemerintahan Daerah. Fokusmedia, Bandung. 